\title{
Fiscal Policy and Inequality in Latin America, 1960-2012
}

\author{
Judith Clifton, Daniel Díaz-Fuentes, and Julio Revuelta
}

\section{Introduction}

Latin America is a region which has been plagued with persistent problems of social cohesion linked to inequality (Bértola and Ocampo 2012; Fitzgerald et al. 2011; Huber et al. 2006; Milanovic and Muñoz de Bustillo 2008; Williamson 2010). Over the long term, the excessive degree of inequality in Latin America was considered an anomaly in international comparisons (Deininger and Squire 1996, 1998). However, over the last two decades, income inequality actually decreased across most countries in the region, though it still remains above the world average (ECLAC 2010; Cornia 2012). With this, Latin America has emerged as a positive anomaly, going against the grain of recent world trends which are heading towards greater inequality (Hvistendahl 2014, Ravallion 2014).

This historical shift in inequality in Latin America has attracted considerable research aiming to uncover the causes of this change (De la Torre 2014; Salazar 2014; Székely 2014). Contributing to this recent literature, this chapter provides new knowledge about the role of fiscal policy on income redistribution in the Latin American context. The role of fiscal policy on income distribution has been at the heart of some of the most controversial economic and political discussions surrounding the history of economic policy (Bastagli et al. 2012; Lindert 2004; Piketty 2014). Today, the role of fiscal policy on income distribution remains highly pertinent, given the distinct positions scholars have taken about its effectiveness as a tool of redistribution in the Latin American context (Arroyo Abad and Lindert 2014; Bastagli et al. 2012; Bárcena and Kacef 2011; Goñi et al. 2011).

We use the available historical data on 18 Latin American countries for the time period 1960-2012 to investigate the impact of public spending and public revenues

J. Clifton $(\varangle) \bullet$ D. Díaz-Fuentes $\bullet J$. Revuelta

University of Cantabria and Cornell University, Cantabria, Spain 
on income inequality, using the Gini index. While previous studies examined the impact of fiscal policy on inequality using data from 1990 onwards — often using a smaller number of countries - our aim is to contribute to the literature by extending the time period to the longest possible due to data restrictions while increasing the number of countries under study to the maximum, 18. Given the turn in fiscal policy from Washington Consensus-style approaches to more progressive ones (Hausmann 1997), and differences in the methodology used to produce the data, we split the time period into two subperiods, 1960-1998 and 1999-2012. Another novelty of this chapter is that we analyze results at the national and urban levels for this second subperiod, which is of interest given the high degree of urbanization in Latin America. We apply several econometric methods, specifications, and definitions of variables, based on fixed and random effects and panel-corrected standard errors. We test the direction and magnitude of the historical effect that fiscal policy has had on income distribution for the period. We examine both the impact of aggregate public spending and public revenues and the main functional categories of spending and taxation.

The rest of the chapter is divided into four sections. In Sect. 2, we present a brief literature review of income inequality and fiscal policy in the Latin American context. In Sect. 3, we present the data and methodology. In Sect. 4, we set out the results of our analysis, at both the general Latin American and specific national levels. Section 5, concludes by presenting the main findings and their implications in terms of fiscal policy.

\section{Inequality and Fiscal Policy in Twentieth-Century Latin America: A Background}

In this section we firstly highlight the main contributions on income inequality, highlighting those with particular relevance for the Latin American context. We then turn to analyze the literature on the importance of fiscal policy for inequality in Latin America, and then set out our approach in this chapter in the context of this most recent literature.

\subsection{Income Inequality in Latin America: A Contemporary Debate}

Economic inequality defines in general the differences among individuals or groups in a given population - which may be regional, national, or international-as regards wealth, resources, income, or opportunities (World Bank 2006). The concern about economic inequality in capitalist development was a central issue for the classical political economists from Adam Smith to John Stuart Mill. In contrast, economic inequality within and among countries became a secondary concern for 
neoclassical economists from the last quarter of nineteenth century onwards. As regards income inequality in particular, one of the most influential exceptions was Kuznets $(1953$, 1955), whose studies gave support to the "inverted-U Kuznets hypothesis." This hypothesis predicted a pattern of increasing income inequality in the early stages of economic growth, while it also predicted that at higher levels of economic growth, inequality would decrease. In general, from the 1950s to the 1990s, the literature on inequality and development was divided on the validity of the Kuznets hypothesis. Much of the earlier literature supported the Kuznets hypothesis (Milanovic 1994; Higgins and Williamson 1999; Barro 2000). However, more recently, scholarship identified limits to the general validity of the hypothesis (Deininger and Squire 1996, 1998; Atkinson 1997; Bértola 2005). In any case, until the 1990s, the main problem characterizing most of the attempts to verify or otherwise test the hypothesis was associated with the attempts to identify temporal relations by means of cross-country data. A key contribution was Deininger and Squire (1996), which overcame this problem through the use of panel data and regional dummies. By introducing Latin American countries as a dummy, their results showed that the inverted-U Kuznets hypothesis vanished. In other words, the authors demonstrated that the cross-sectional results of previous works that had supported the Kuznets hypothesis had been biased by the relatively high level of inequality of the group of middle-income Latin American countries.

So, the high levels of inequality in Latin American have been considered an anomaly in the international patterns of income distribution. Indeed, the reduction of inequality in Latin America over the last few decades, along with the shift of some countries from low- to middle-income levels and increasing inequality levels among the higher income countries, has significantly flattened the Kuznets curve in the world economy. Despite this, with or without empirical evidence for the Kuznets hypothesis, many economists and politicians believed that increasing inequality was a necessary condition for economic growth at the earlier stages of development. Hence, policy efforts to reduce inequality were held to impede or reduce economic growth (Ravallion 2014). This assumption was reinforced by argument of the so-called big trade-off between equality and efficiency as predicted by Okun (1975). He claimed that all "societies inevitably face an invidious choice between efficient production and equitable wealth and income distribution." Moreover, he stated that "Not only more equal distribution of incomes reduce incentives to work and invest, but the effort to redistribute." " Okun's assumption has been influential in providing reasons to avoid income redistribution through fiscal policy.

Latin America constitutes a middle-income region with well-known problems of development and social cohesion linked to long-term inequality as regards wealth, income, and opportunities (Bértola and Ocampo 2012; Milanovic and Muñoz de Bustillo 2008; Huber et al. 2006; Sánchez-Ancochea 2014; Williamson 2010). As Fig. 1 shows, from the first decade of the 2000s, income inequality actually decreased across most countries in the region, though inequality in Latin America is

\footnotetext{
${ }^{1}$ This apparent trade-off between efficiency and equality has been recently challenged by IMF researchers (Berg and Ostry 2011; Ostry et al. 2014).
} 


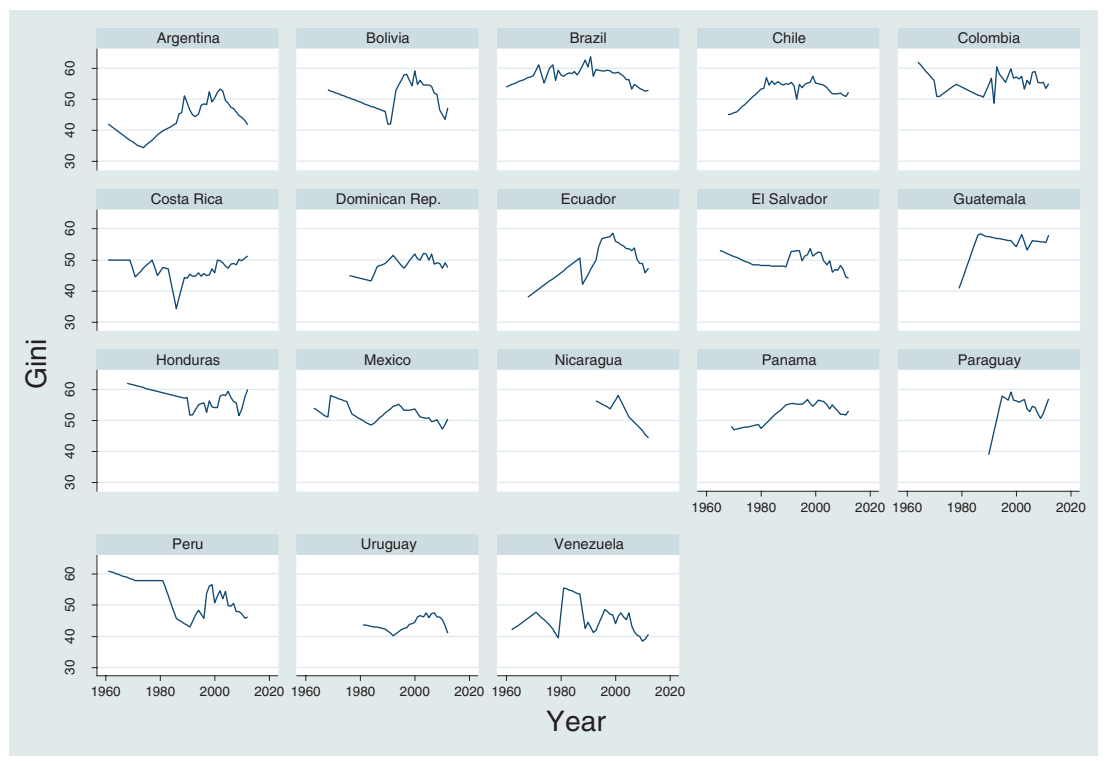

Fig. 1 Gini coefficient in Latin America, 1960-2012. Source: Elaborated by authors using data from Milanovic (2014)

still above the world average (ECLAC 2010, 2014; Cornia 2012; Salazar 2014). Indeed, Latin America now represents a positive anomaly at the international level, since the reduction in income inequality goes against the grain of recent trends in the rest of the world, which are heading towards greater inequality (Hvistendahl 2014; Ravallion 2014).

As renewed attention around issues of inequality preoccupies scholars of social science, the humanities, and even science ${ }^{2}$ in the contemporary period, a central question is to explain why inequality is decreasing in Latin America, after decades of persistent inequality while, in the rest of the world, inequality is again on the rise (Atkinson and Piketty 2010; Milanovic 2013; OECD 2008; Piketty 2014; Piketty and Saez 2014).

A significant number of scholars have been attracted to the task of identifying the major political and economic determinants of the historical shift in income inequality in Latin America since the 2000s (Anderson and Palacio 2014; Astorga 2014; Cornia 2012, 2014a, b; González and Martner 2012; Lustig et al. 2013; McLeod and Lustig 2011; Tsounta and Osueke 2014; De la Torre 2014). Regarding the possible political determinants, scholars have studied in particular the effects of democracy and progressive government on reducing inequality (McLeod and Lustig 2011; Milanovic and Muñoz de Bustillo 2008; Montecino 2011). Other scholarly works

\footnotetext{
${ }^{2}$ See, for example, how inequality has become a key international issue among scientists, as summarized in a special issue of American Association of Advancement of Science (Chin and Culotta 2014).
} 
have focused on institutional factors such as human capital and labor market failures (Lustig et al. 2013; Tsounta and Osueke 2014; Irigoin and Giardili 2014). Finally, scholars have investigated the extent to which economic factors have determined reduced inequality, including foreign trade and foreign direct investment (Székely and Sámano-Robles 2014; Tsounta and Osueke 2014). However, much less attention has been paid to the role of fiscal policy as regards this historical shift in Latin America, and it is to this we now turn.

\subsection{Fiscal Policy and Income Distribution in Latin America}

The role of fiscal policy in income distribution has been at the heart of some of the most controversial economic and political discussions throughout history (Comín and Díaz-Fuentes 2005; Bastagli et al. 2012; Lindert 2004; Piketty 2014). This question has also been examined in the Latin American context (Arroyo Abad and Lindert 2014). The question is a highly pertinent one for Latin America today. Fiscal policy has been held to be an important tool of redistribution in the Latin American context (Bárcena and Kacef 2011; González and Martner 2012; Goñi et al. 2011). Bastagli et al. (2012) demonstrated that, even in the context of a worldwide trend towards increased inequality, fiscal policy mattered. This is because the level of available income before and after fiscal policy (tax and transfer) shows a wide difference among countries due to tax incidence, tax progressivity, and social spending policies.

Despite this debate on fiscal policy and income distribution, there is a lack of empirical work which identifies the variables of public spending and revenue that affect income distribution in Latin America. Among the existing studies that consider fiscal policy and income distribution, Goñi et al. (2011) described the performance of tax and transfers on income distribution in six Latin American countries in comparison to Western Europe at the beginning of the 2000s. This study concluded that the fiscal system proved weak as regards reducing income inequality in Latin America. Gómez Sabaini and Martner (2008) compared the Gini indices before and after taxes in a broad sample of Latin American countries. They found that fiscal policy was slightly more effective than the Goñi et al. (2011) study, but this finding was not significant until around 2005. More recently, Cornia (2012) concluded that tax, social spending, and other institutional variables were significant factors as regards income distribution in Latin America. In a further study, Cornia et al. (2014) updated and confirmed their results, that is, that taxation had progressive effects on income distribution.

More specifically, two recent contributions sought to identify the effects of taxation and public spending on income distribution for most Latin American countries from the 1990s onwards. Working from the United Nations-Economic Commission for Latin America and the Caribbean (ECLAC), González and Martner (2012) identified a positive role of fiscal policy on income distribution, in particular social spending, education, public investment, and a progressive tax system, in addition to other institutional and macroeconomic variables. From the International Monetary 
Fund (IMF), Tsounta and Osueke (2014) found that government policies could explain more than a half of the reduction in income inequality in Latin American countries in the first decade of the 2000s, while education spending and tax revenues were the most significant identified variables of income redistribution.

Our study builds on this literature by analyzing the effects of fiscal policies on income distribution for different periods and 18 Latin American countries. We test whether public spending and public revenues and its main components determined income distribution for the subperiods 1960-1998 and 1999-2012. As regards public revenues, we enquire whether the public revenue incidence had a significant effect on income distribution and whether each tax category had different effects on income distribution. It is generally assumed in the literature that typical direct taxes, such as personal income taxes, are more progressive in redistributive terms than indirect taxes, such as taxes on goods and services. However, given that there are other categories of direct and indirect taxes that affect income distribution, we have also considered the effects of property taxes and social contributions. Thus our derived questions are these: Which categories of taxes had more effect on income distribution? Did the progressiveness of the tax structure determine income distribution? It is important to state that we have not considered other variables of fiscal efficiency such as tax compliance, tax evasion, or horizontal exemptions which may also feasibly affect income distribution.

In addition, we enquired whether public spending had a significant effect on income inequality. Given that spending categories could have different progressive or regressive effects on income distribution, we examined the effects of different categories of public spending, including education, health, social security, and housing on income distribution. Our approach, therefore, to assessing public spending goes beyond examining only education, which is the category most commonly dealt with by scholars, and broadens the study to items that typically receive much less attention: health, social security, and housing, which may well have a significant effect.

As regards the evolution of public spending and public revenues in Latin America, as seen in Fig. 2, we observe a great heterogeneity in national fiscal policies. In some countries, such as Brazil and Ecuador, fiscal policy has assumed a great direct relevance while, in others, the public sector has played a more passive role, as in the cases of Guatemala and Paraguay. However, we can also note some common elements associated with the region as a whole, namely, the growth of both public spending and public revenues (Díaz-Fuentes and Revuelta 2011). Despite these increases, these variables still have less weight as a percentage of GDP in Latin America than do they in the average of OECD countries (ECLAC 2014; OECD 2015). In addition, there are significant differences between Latin American countries and OECD members in terms of tax. Broadly speaking, in Latin America there is a bias towards indirect taxation while tax systems in OECD countries are biased towards direct taxes (ECLAC 2014; OECD 2015). Another important difference is that fiscal policies in Latin America are in general much less progressive as regards their capacity to redistribute than those in OECD countries (Amarante 2014). 


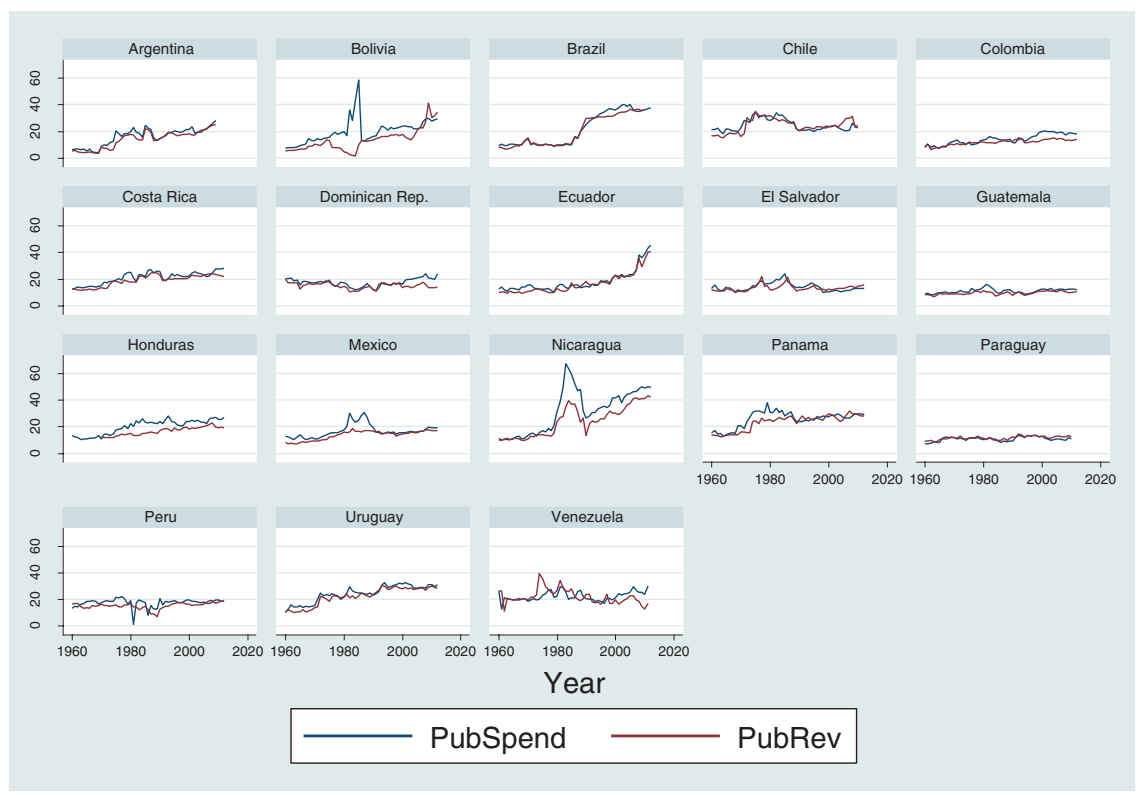

Fig. 2 Public spending and public revenues in Latin America, 1960-2012. Source: Elaborated by authors using data from ECLAC (2014) and MOxLAD (2014)

\section{Data and Methodology}

In order to empirically analyze the impact of fiscal policy on inequality in Latin America we first describe the variables used to measure inequality and fiscal policy, as well as the control variables. These are set out in Table 1. To measure income inequality we use the Gini index. The Gini index is the most common indicator used by scholars when analyzing income inequality from the 1960s across Latin America (and other regions) for extended periods. Since the aim of this chapter is to conduct a historical analysis including the greatest possible time period, the Gini index suits our study well.

Given the different sources for the estimation of the Gini index along time, we follow the approach as found in Milanovic (2014). This approach reduces the problem of temporal and international comparability through the compilation and standardization of a wide series of Gini coefficients based on household surveys from $1950,{ }^{3}$ and thus avoids the use of other sources produced by regressions or shortcuts. These remain today the best Gini indices available for international comparison over the long term. However, despite the fact that issues around comparability have been reduced, it is still desirable to use other estimations of the Gini index from more recent years which are derived from more homogeneous sources.

\footnotetext{
${ }^{3}$ In the case of Latin America, the Milanovic Gini index begins in the 1960s.
} 
Table 1 Variable descriptions and data sources

\begin{tabular}{|c|c|c|}
\hline Variable & Source & Description \\
\hline Gini & Milanovic (2014) & Standardized Gini index \\
\hline Gininat & ECLAC (2014) & National Gini index \\
\hline Giniurb & ECLAC (2014) & Urban Gini index \\
\hline PubSpe & $\begin{array}{l}\text { ECLAC (2014), } \\
\text { MoXLAD (2014) }\end{array}$ & Total public spending (\% GDP) \\
\hline PubSpeEdu & $\begin{array}{l}\text { ECLAC (2014), } \\
\text { MoXLAD (2014) }\end{array}$ & Public spending on education ( $\%$ GDP) \\
\hline PubSpeHea & ECLAC (2014) & Public spending on health (\% GDP) \\
\hline PubSpeSocSec & ECLAC (2014) & Public spending on social security (\% GDP) \\
\hline PubSpeHou & ECLAC (2014) & Public spending on housing (\% GDP) \\
\hline PubRev & $\begin{array}{l}\text { ECLAC (2014), } \\
\text { MoXLAD (2014) }\end{array}$ & Total public revenues (\% GDP) \\
\hline PubIncTax & $\begin{array}{l}\text { ECLAC (2014), } \\
\text { MoXLAD (2014) }\end{array}$ & Personal income taxes (\% GDP) \\
\hline PubPropTax & ECLAC (2014) & Property taxes (\% GDP) \\
\hline PubTaxG\&S & ECLAC (2014) & Indirect taxes on goods and services (\% GDP) \\
\hline SocCont & ECLAC (2014) & Social contributions (\% GDP) \\
\hline GDPpc & World Bank (2014) & GDP per capita \\
\hline Unemp & World Bank (2014) & Unemployment rate (\%) \\
\hline Depend & World Bank (2014) & Dependency rate; Pop. 65 and over/Pop. 15-64 (\%) \\
\hline Pop & World Bank (2014) & Total population \\
\hline Open & World Bank (2014) & Openness: (Exports + imports)/GDP (\%) \\
\hline ToT & World Bank (2014) & Terms of trade \\
\hline Invest & $\begin{array}{l}\text { World Bank (2014), } \\
\text { MoXLAD (2014) }\end{array}$ & Investment (\% GDP) \\
\hline Inf & World Bank (2014) & Annual variation of GDP deflator (\%) \\
\hline Dem & Marshall et al. (2014) & Institutionalized democracy \\
\hline NatRes & World Bank (2014) & Natural resource rents (\% GDP) \\
\hline
\end{tabular}

In the case of Latin America, the ECLAC has provided data on the Gini index since 1990. ${ }^{4}$ As this is the higher quality of the two datasets and since the turn of fiscal policy from Washington Consensus inspired approaches to more progressive ones (Hausmann 1997), we divided the sample of our analysis into two subperiods: 1960-1998, using the Milanovic Gini standardizations, and 1999-2012, using the

\footnotetext{
${ }^{4}$ An alternative source to ECLAC (2014) is SEDLAC (2014). However, given the differences between the values of the Gini coefficients of both sources, we opt to use the ECLAC data as it corrects for income underreporting. According to Montecino (2011) "the key difference between data from SEDLAC and ECLAC is that the latter corrects for income underreporting-when households in an income survey underreport their true amount of income, thus biasing the measurement of inequality - while the former does not. Because income underreporting is likely more pronounced in wealthier households, failing to adjust for underreporting is expected to lead to a lower and biased estimate of inequality."
} 
ECLAC (2014) Gini index. In this second subperiod, use of ECLAC data allows for the separation of inequality across the nation as a whole (Gininat) and also inequality in cities (Giniurb). We acknowledge that the Gini coefficient has some limitations (Atkinson 1997), not least, because it is an index of relative concentration which provides synthetic information on the income distribution in a single coefficient. For example, the Gini index has been criticized on the grounds it fails to capture issues related to income polarization, at the top and bottom income levels. In addition, it does not capture all kinds of incomes, such as those related to income from capital. Despite these shortcomings, the advantages of using the Gini index as regards its availability, information, and simplicity outweigh the disadvantages. In addition, using the Gini index facilitates a longer term comparison, although we need to exercise caution as regards potential biases when interpreting results.

Turning to the dimension of fiscal policy, we consider its two principal variables, public spending (PubSpe) and public income or revenue (PubRev). We use both variables at the aggregate level as well as at the functional level, that is, social spending related to income redistribution, on the one hand, and to tax structure, on the other. Thus, public social spending is disaggregated into public spending on education (PubSpeEdu), health (PubSpeHea), social security (PubSpeSocSec), and housing (PubSpeHou). As regards revenues, we consider social contributions (SocCont), as well as the main components of the tax structure. These are income (PubIncTax), property (PubPropTax), and goods and services (PubTaxG\&S). For the subperiod 1999-2012, we have data on all these variables, whereas for the subperiod 1960-1998, less disaggregated data on spending and income is available.

Finally, we use a series of control variables that have been identified as potential determinants of inequality, income distribution, and wealth in the theoretical and empirical literature. Thus, we consider the logarithm of GDP per capita (lnGDPpc), as considered by González and Martner (2012), Huber et al. (2006), Milanovic (1994), McLeod and Lustig (2011), Roine et al. (2009), Tsounta and Osueke (2014), and Williamson (2010); unemployment rate (Unemp) as used in González and Martner (2012); dependency rate (Depend) as deployed in Cornia (2012) and Lee et al. (2013); logarithm of population (lnPop) as used by Roine et al. (2009); trade openness (Open) as used in Lee et al. (2013) and Roine et al. (2009); terms of international trade (ToT) by Cornia (2012), Montecino (2011), and McLeod and Lustig (2011); investments (Invest) as found in Lee et al. (2013); inflation (Inf) as used in González and Martner (2012), Montecino (2011), and McLeod and Lustig (2011); democratic institutions (Dem) as used in Cornia (2012) and Huber et al. (2006); and natural resource rents (NatRes) as utilized in Loayza et al. (2013).

To test the adequate use of these variables we estimated the correlation coefficients among them, and did not detect serious correlation problems that would impede their use, as shown in Table 2. Other variables were considered, such as life expectancy or secondary enrollment rate. However, when estimating the correlations with the rest of the variables of the sample we observed problems of high correlation that could bias the estimations and invalidate them as control variables.

As regards the appropriate methodology to analyze the impact of fiscal policy on inequality, a review of the literature on inequality shows that most authors use OLS 


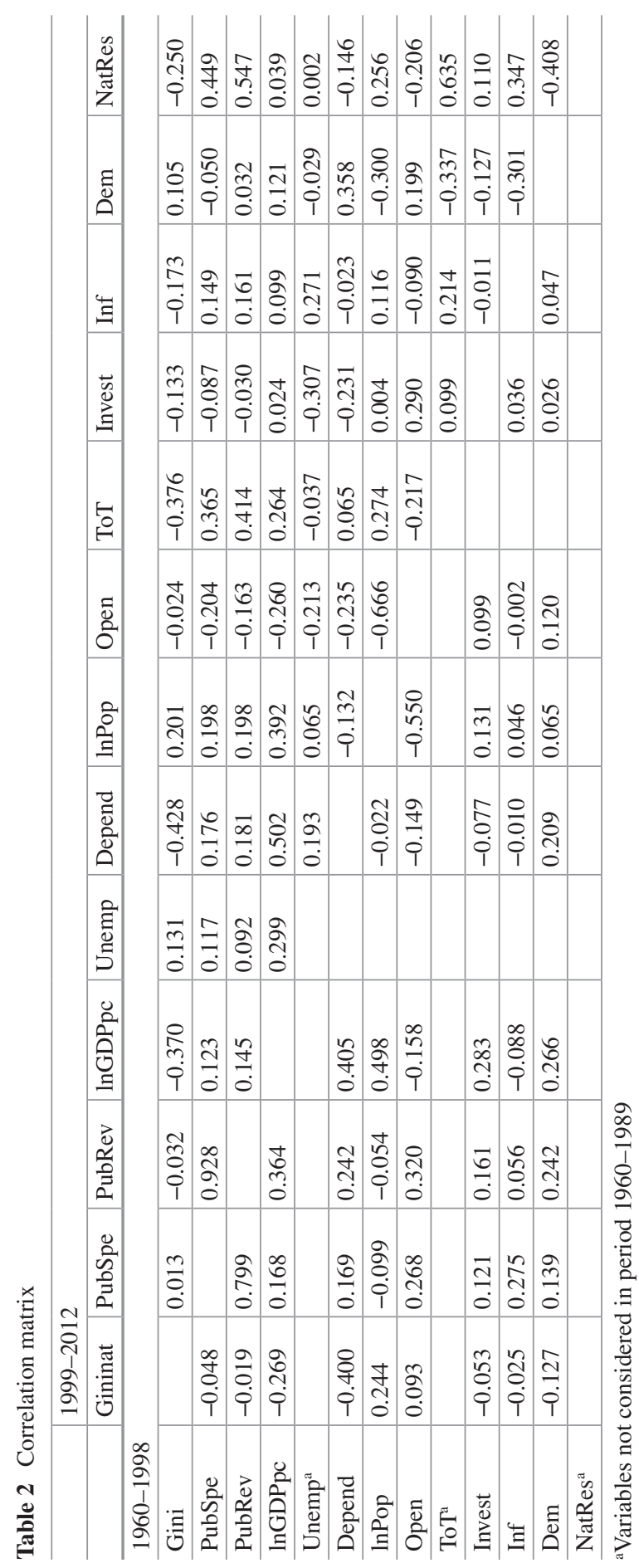


regression in order to analyze potential determinants of inequality (González and Martner 2012; Lee et al. 2013; Milanovic 1994; Williamson 2010). In our case, since we are using an unbalanced panel, which includes a sample of 18 countries and 39 or 14 temporal periods, depending on the subperiod under analysis (1960 1998 or 1999-2012), the use of OLS could produce bias in the results. We therefore opt to estimate a series of models which have diverse assumptions about the sample and are more robust. Following McLeod and Lustig (2011), Montecino (2011), and Tsounta and Osueke (2014), we use as basic models the panel regressions with fixed and random effects, depending on the result of the Hausman test. We correct for the presence of serial correlation and heteroskedasticity, testing these with the Wooldridge test and the modified Wald statistics for groupwise heteroskedasticity test, respectively, and correlation across panels using the panel-corrected standard error model, also used by Huber et al. (2006). In this way, we perform diverse regressions adapting the following general equation to the fixed effect, random effect, and panel-corrected standard error models:

$$
\text { Gini }_{i t g}=F_{i t k}+X_{i t m}+\varepsilon_{i t}
$$

where $i$ includes each of the 18 Latin American countries in the sample (Argentina, Bolivia, Brazil, Chile, Colombia, Costa Rica, the Dominican Republic, Ecuador, El Salvador, Honduras, Guatemala, Mexico, Nicaragua, Panama, Paraguay, Peru, Uruguay, and Venezuela); $t$ is the year; $g$ is the Gini index considered (Gini, Gininat, Giniurb); $F$ is a vector that includes $k$ fiscal variables considered (PubSpeEdu, PubSpeHea, PubSpeSocSec, PubSpeHou, PubIncTax, PubPropTax, PubTaxG\&S, SocCont); and $X$ is a vector of variables of $m$ control variables (lnGDPpc, Unemp, Depend, InPop, Open, ToT, Invest, Infl, Dem, NatRes). Estimations are performed separately for the subperiods 1960-1998 and 1999-2012.

\section{Results}

When the null hypothesis in the Hausman test is rejected we use the fixed effect model, using the random effect model in the other case. The rejection of the null hypothesis both in the Wald test for heteroskedasticity and in the Wooldridge test signals potential problems of heteroskedasticity and serial correlation. This makes it worthwhile to consider the panel-corrected standard error model.

We now focus on the results of the regressions, looking first at those obtained for the first subperiod, 1960-1998, as shown in Table 3. Looking across the two components of fiscal policy for which we have available information-public spending on education and personal income taxes - we find evidence showing how these policies were either neutral or regressive in their effect on income distribution. In this subperiod, among the control variables, two in particular stand out in most of the estimated models. Both an aging population and increasing openness were found to have a regressive effect on inequality. Our results confirm the findings of 
Table 3 Income distribution, public spending, and tax structure, at the national level, 18 Latin American countries, 1960-1998 (dependent variable: Gini)

\begin{tabular}{l|l|l|l|l|l|l|l|l}
\hline & $\mathrm{FE}$ & & PCSE & & FE & & PCSE & \\
\hline Constant & 90.213 & $* * *$ & 32.759 & $* * *$ & 98.161 & $* * *$ & 23.329 & $* * *$ \\
\hline PubSpeEdu & 0.325 & & 0.199 & & & & & \\
\hline PubIncTax & & & & & 0.234 & $* *$ & 0.141 & \\
\hline lnGDPpc & 4.524 & $* * *$ & -4.377 & $* * *$ & 1.165 & & -4.893 & $* * *$ \\
\hline Depend & 1.337 & $* * *$ & -0.209 & & 1.843 & $* * *$ & -0.114 & \\
\hline InPop & -5.414 & $* * *$ & 3.195 & $* * *$ & -4.646 & $* * *$ & 3.587 & $* * *$ \\
\hline Open & 0.078 & $* * *$ & 0.044 & $* * *$ & 0.120 & $* * *$ & 0.048 & $* * *$ \\
\hline Invest & -0.179 & $* * *$ & -0.019 & & -0.054 & & -0.011 & \\
\hline Inf & -0.000 & $*$ & 0.000 & & -0.000 & & -0.000 & \\
\hline Dem & 0.148 & $* *$ & 0.016 & & -0.099 & & 0.018 & \\
\hline$N$ & 478 & & 478 & & 403 & & 403 & \\
\hline$R^{2}$ & 0.15 & & 0.78 & & 0.15 & & 0.78 & \\
\hline$F$ & 10.94 & $* * *$ & & & 11.38 & $* * *$ & & \\
\hline Wald Chi ${ }^{2}$ & & & 78.98 & $* * *$ & & & 85.12 & $* * *$ \\
\hline Hausman test & 69.98 & $* * *$ & & & 67.62 & $* * *$ & & \\
\hline Wald test for heteroskedasticity & 3142.71 & $* * *$ & & & 754.58 & $* * *$ & & \\
\hline Wooldridge test & & & 18.004 & $* * *$ & & & 17.077 & $* * *$ \\
\hline
\end{tabular}

* Significant at $10 \%$.

** Significant at $5 \%$.

*** Significant at $1 \%$

many scholars: in this subperiod, fiscal policy did little or nothing to reduce inequalities in the region. This contrasts sharply with the next subperiod, as we now explain.

Since the late 1990s, fiscal policy shifted away from Washington Consensus approaches towards more progressive ones. This was mainly due to two main changes: firstly, the coming into power of more center-left or left governments, starting in Venezuela in 1999, when Chávez was elected president of Venezuela, followed by Kirchner's and Lula's victory in Argentina and Brazil in 2003, the election of Vázquez in Uruguay in 2005, and so on, and secondly, policy transfer as regards the dominant ideas circulating in international organizations as to best practice fiscal policy (Hausmann 1997).

Analyzing this second subperiod, spanning the years from 1999 to 2012, we find fiscal policy making a difference to inequality in Latin America. Our findings therefore confirm the findings of other scholars that a shift in policy had observable progressive consequences. To explore this shift in more detail, we first analyze the estimations of the impact of fiscal policy on income inequality at the national level, as presented in Table 4. Here, looking inside the functional structure of public spending, the evidence is mixed. We can observe that public spending on health has reduced inequality, but we can also see how public spending on housing has exacerbated inequalities further. However, when we look inside the category of tax structure, we can observe that several elements have contributed to inequality 
Table 4 Income distribution, public spending, and tax structure, at the national level, 18 Latin American countries, 1999-2012 (dependent variable: Gininat)

\begin{tabular}{|c|c|c|c|c|c|c|c|c|}
\hline & $\mathrm{FE}$ & & PCSE & & FE & & PCSE & \\
\hline Constant & -170.025 & $* *$ & 26.385 & $* * *$ & 50.495 & & 24.909 & $* * *$ \\
\hline PubSpeEdu & -0.189 & & 0.186 & & & & & \\
\hline PubSpeHea & -1.217 & $* * *$ & -0.706 & $* *$ & & & & \\
\hline PubSpeSocSec & -0.161 & & 0.230 & & & & & \\
\hline PubSpeHou & 0.391 & & 0.784 & $* *$ & & & & \\
\hline PubIncTax & & & & & -0.889 & $* * *$ & -0.500 & $* *$ \\
\hline PubPropTax & & & & & -0.358 & & 0.638 & \\
\hline PubTaxG\&S & & & & & -0.604 & *** & 0.139 & \\
\hline SocCont & & & & & -0.711 & $* *$ & 0.177 & \\
\hline $\operatorname{lnGDPpc}$ & -6.226 & $* *$ & -2.456 & $* *$ & -2.309 & & -3.043 & $* * *$ \\
\hline Unemp & 0.202 & $*$ & 0.324 & $* * *$ & 0.132 & & 0.286 & $* * *$ \\
\hline Depend & -1.808 & $* * *$ & -0.414 & $* *$ & -1.467 & *** & -0.418 & * \\
\hline $\ln$ Pop & 17.541 & $* * *$ & 2.773 & $* * *$ & 2.786 & & 3.128 & $* * *$ \\
\hline Open & -0.094 & $* * *$ & 0.049 & $* * *$ & -0.030 & & 0.051 & $* * *$ \\
\hline ToT & 0.003 & & -0.009 & & -0.026 & $* * *$ & -0.020 & \\
\hline Invest & 0.029 & & -0.118 & & 0.190 & $* * *$ & -0.030 & \\
\hline Inf & 0.013 & & -0.026 & & -0.039 & $*$ & -0.040 & $* *$ \\
\hline Dem & -0.089 & & 0.283 & & 0.184 & & 0.403 & $* *$ \\
\hline NatRes & -0.055 & & -0.072 & & 0.101 & $* * *$ & -0.025 & \\
\hline$N$ & 175 & & 175 & & 210 & & 210 & \\
\hline$R^{2}$ & 0.90 & & 0.98 & & 0.78 & & 0.98 & \\
\hline$F$ & 18.63 & $* * *$ & & & 22.58 & $* * *$ & & \\
\hline Wald $\mathrm{Chi}^{2}$ & & & $220,286.98$ & $* * *$ & & & $182,262.42$ & $* * *$ \\
\hline Hausman test & 28.68 & $* * *$ & & & 25.30 & ** & & \\
\hline $\begin{array}{l}\text { Wald test for } \\
\text { heteroskedasticity }\end{array}$ & 87.65 & $* * *$ & & & 57.16 & $* * *$ & & \\
\hline Wooldridge test & & & 38.589 & $* * *$ & & & 29.571 & $* * *$ \\
\hline
\end{tabular}

* Significant at $10 \%$

**Significant at $5 \%$

*** Significant at $1 \%$

reduction. Personal income taxes, social contributions, and taxes on goods and services are all observed to act progressively on inequality. Overall, we observe how public revenues contribute more to reducing inequality than public spending.

We now focus on the determinants of inequality at the urban level. Table 5 presents the results of our analysis which tracks the evolution of the impact of fiscal policies on the Gini index in urban zones in Latin America. We first look inside the functional components of public spending, and observe how public spending on urban health reduces inequality. In contrast, we observe that spending on urban housing and social security is regressive. We then turn to looking inside the functional components of the tax structure, and find that personal income taxes, social contributions, and taxes on goods and services help reduce urban inequality. 
Table 5 Income distribution, public spending, and tax structure, urban level, 18 Latin American countries, 1999-2012 (dependent variable: Giniurb)

\begin{tabular}{l|l|l|l|l|l|l|l|l}
\hline & RE & & PCSE & & RE & & PCSE & \\
\hline Constant & 25.057 & $* *$ & 34.862 & $* * *$ & 27.113 & $* *$ & 18.877 & $* *$ \\
\hline PubSpeEdu & 0.153 & & -0.012 & & & & & \\
\hline PubSpeHea & -1.728 & $* * *$ & -0.995 & $* * *$ & & & & \\
\hline PubSpeSocSec & -0.119 & & 0.390 & $* * *$ & & & & \\
\hline PubSpeHou & 0.655 & $*$ & 0.464 & & & & & \\
\hline PubIncTax & & & & & -1.070 & $* * *$ & -0.516 & $* *$ \\
\hline PubPropTax & & & & & 0.947 & $*$ & 0.135 & \\
\hline PubTaxG\&S & & & & & -0.914 & $* * *$ & -0.152 & \\
\hline SocCont & & & & & -0.995 & $* * *$ & -0.294 & \\
\hline lnGDPpc & -0.572 & & -0.704 & & 0.686 & & -1.652 & $* *$ \\
\hline Unemp & 0.309 & $* * *$ & 0.491 & $* * *$ & 0.309 & $* * *$ & 0.418 & $* * *$ \\
\hline Depend & -0.297 & & -0.443 & $* * *$ & -0.292 & & -0.080 & \\
\hline lnPop & 2.687 & $* *$ & 1.563 & $* * *$ & 1.932 & & 2.797 & $* * *$ \\
\hline Open & -0.041 & $* *$ & 0.003 & & -0.029 & $*$ & 0.017 & \\
\hline ToT & -0.035 & $* * *$ & -0.029 & $*$ & -0.039 & $* * *$ & -0.022 & \\
\hline Invest & -0.088 & & -0.091 & & 0.199 & $* * *$ & 0.003 & \\
\hline Inf & 0.011 & & 0.009 & & 0.014 & & 0.005 & \\
\hline Dem & -0.108 & & 0.124 & & -0.040 & & 0.109 & \\
\hline NatRes & -0.027 & & 0.041 & & 0.066 & $*$ & 0.028 & \\
\hline$N$ & 186 & & 186 & & 218 & & 218 & \\
\hline$R^{2}$ & 0.88 & & 0.98 & & 0.87 & & 0.98 & \\
\hline Wald Chi ${ }^{2}$ & 833.22 & $* * *$ & $229,528.65$ & $* * *$ & 1105.03 & $* * *$ & $166,914.20$ & $* * *$ \\
\hline Hausman test & 7.35 & & & & 11.06 & & & \\
\hline Wald test for & 201.77 & $* * *$ & & & 61.39 & $* * *$ & & \\
\hline heteroskedasticity & & & & & & & & $* * *$ \\
\hline Wooldridge test & & & 46.167 & $* * *$ & & & 19.500 & \\
\hline Signifcant at & & & & & & & & \\
\hline
\end{tabular}

*Significant at $10 \%$

** Significant at $5 \%$

*** Significant at $1 \%$

However, we find property taxes are regressive. In general terms, tax structure is more progressive than public spending in terms of reducing inequality.

It is illuminating to compare the effects of fiscal policy on inequality at the national level with those acting in the urban context, since the performance of a given policy may have a varying effect depending on the context. For example, fiscal policy that may not be observed to influence inequality at the national level may well do so at the urban level, with important practical consequences for policy makers. When we do so, we find some evidence of differential effects of fiscal policy according to its context. First, some fiscal policy which is important at the national level proves to be even more significant in urban areas. Here we have the case of public spending on health, personal income taxes, taxes on goods and services, and social contributions. These were significant factors in reducing inequality at the 
national level, but had an even more intense effect at the urban level. In the opposite direction, public spending on housing, which was found to be regressive in urban areas, was even more intensely regressive at the national level. Then, we observe some policies which are important in determining inequality in urban regions, but they are not significant at the national level. Here, public spending on social security and property taxes show a regressive effect in urban areas, but not at the national level.

As regards the control variables in this subperiod, population size and unemployment rate are related to more inequality at both the national and urban scales. The rest of the control variables are influential at different scales. For example, increases in the dependency rate and GDP per capita reduce inequality at the national level. Meanwhile, increases in openness and terms of trade reduce urban inequality.

When calculating the interaction effect between the estimated coefficient and public spending and revenue levels for each Latin American country, we observe important national differences. As regards public spending on health, we find that this is most progressive in Brazil, Argentina, and Uruguay, while it is least progressive in Bolivia, Guatemala, and the Dominican Republic. For personal income taxes, Brazil, Peru, and Chile stand out for achieving the highest degrees of progressivity while, in contrast, Paraguay, Guatemala, and the Dominican Republic are the countries with the lowest progressive effect. Regarding social contributions, Brazil, Argentina, Costa Rica, and Venezuela led the way in the region, while the Dominican Republic, Venezuela, and Chile exhibited the lowest range of progressivity using this tool. Finally, as regards public spending on housing, which we generally found to be regressive, Guatemala, Brazil, and Costa Rica were those countries with a highest regressive effect.

\section{Conclusions}

This chapter sought to enquire whether fiscal policy impacted upon inequality in Latin America from 1960 to 2012. One of the aims of this chapter was to extend the number of Latin American countries included in our sample to the longest time period possible, given data availability. Given the shift in fiscal policy to progressive approaches and the differences in the methodology used to produce the data, we split the time period into two subperiods, 1960-1998 and 1999-2012. In this second subperiod, we analyzed the effects of fiscal policy on income inequality at the national and urban levels, to produce new knowledge about the potentially differential effects of fiscal policy. Our chapter also contributes to knowing more about the role of fiscal policy in the region by disaggregating fiscal policy into subcomponents, both for public spending and for public revenue. Our results clearly show that fiscal policy was much more influential on inequality in the second subperiod than the first. Our main findings are the following.

For the subperiod 1960-1998, fiscal policy in general seemed to have either a regressive or nonsignificant relationship with inequality. Moreover, when some of its components were associated with inequality, this was in the direction of increasing 
income inequality. For example personal income taxes, which could potentially be implemented in order to increase income redistribution and level equal, were associated with actually increasing income inequality in this earlier period.

This contrasts sharply with our findings in the second period, from late 1990s, where we find that fiscal policy significantly reduced regional inequality. Disaggregating fiscal policy into its two main components, public spending and public revenues, we find that both have a significant and positive effect on inequality reduction. Overall, the effect of public revenues on inequality was more significant than that of public spending. The most significant components of public revenues and public spending to contribute to reducing inequality at the national level were spending on health, personal income taxes, taxes on goods and services, and social contributions.

When contrasting analysis across the national and urban levels, we found that most of the fiscal instruments under analysis had a much more intense effect at the urban than the national level. This means that it is the Latin American urban areas which are most seeing the benefits of fiscal policy on income inequality, rather than the rural areas. Of particular importance in decreasing inequality at the urban level are personal income taxes, taxes on goods and services, social contributions, and public spending on health. In contrast, public spending on housing, found regressive in urban areas, was even more intensely regressive at the national level. Certain fiscal policies show significant effects in urban areas but they are not significant at the national level. This is the case of public spending on social security and property taxes, which were found to be regressive only in urban areas.

In addition, there are some interesting national differences as regards fiscal reform and policy transfers across the region. Broadly speaking, some governments have taken strides to deepen income tax reform, including the implementation of property taxes, leading to an increased tax incidence, and in turn to greater equality. Other governments, however, have proved unwilling or unable to implement real reform. To take two extreme cases, the Brazilian Government has successfully implemented many progressive taxation reforms, particularly income tax. The other extreme is found in the Guatemalan Government, which has proved reluctant to take on tax reform; in consequence, inequality levels have failed to decline significantly. Further research is required to unravel and evaluate the varieties of fiscal reform across countries.

Our chapter shows showed that fiscal policy in Latin America has played an essential role in reducing inequality. Moreover, further extension of fiscal policy has a huge potential. Fiscal policies - in particular tax reforms - in Latin America have embarked on a path of convergence with OECD members, similar to what occurred in Spain and Portugal from the 1980s onwards (Díaz Fuentes 1994; Comín and Díaz-Fuentes 2005; Díaz-Fuentes and Revuelta 2013). It is interesting to reflect on the extent to which there may be a process of international policy transfer going on in this field. For example, the OECD is currently expanding to emerging countries, now comprises two Latin American countries-Mexico and Chile-and has two candidates-Colombia and Costa Rica (Clifton and Díaz-Fuentes 2014). Even though there are still differences as regards the tax burden, this amounts to an average of $34 \%$ in OECD members in 2012 (OECD 2015), and only $25 \%$ in Latin 
America in the same year (ECLAC 2014), this is to be expected given the different levels of GDP per capita by region. The same could be said of the differences in the relative weight in favor of direct taxes in the OECD countries and indirect taxes in Latin America.

Coinciding with other recent studies, this chapter offers clear empirical evidence that certain fiscal policies have significantly contributed to reducing income inequalities in the region. For example, increases in tax incidence and public spending in general, and reforms of personal income tax, social contributions, and public spending on health, have clearly contributed to diminishing income inequality. Given we found that direct taxation was more strongly associated with reducing inequality than indirect taxation, an interesting policy option is to encourage governments to increase direct over indirect taxation. This could be a high-impact policy to reduce income inequality, considering that the ratio of indirect to direct taxation in the region was 1.76 in 2012 (ECLAC 2014). This therefore provides solid evidence which can be used to support future fiscal reform by governments committed to further reducing inequality in the region. Clearly, the redistributive effect will also depend on the efficiencies of tax compliance and public spending (Comín and Díaz-Fuentes 2005).

Open Access This chapter is distributed under the terms of the Creative Commons Attribution 4.0 International License (http://creativecommons.org/licenses/by/4.0/), which permits use, duplication, adaptation, distribution and reproduction in any medium or format, as long as you give appropriate credit to the original author(s) and the source, a link is provided to the Creative Commons license and indicate if changes were made.

The images or other third party material in this chapter are included in the work's Creative Commons license, unless indicated otherwise in the credit line; if such material is not included in the work's Creative Commons license and the respective action is not permitted by statutory regulation, users will need to obtain permission from the license holder to duplicate, adapt or reproduce the material.

\section{References}

Amarante, V. (2014). Igualdad y desigualdad en América Latina y el Caribe. In Conference on Latin American inequality in the long run. Buenos Aires.

Anderson, M., \& Palacio, A. (2014). Structural change and the fall of income inequality in Latin America-Agricultural development, inter-sectoral duality and the Kuznets curve. In Conference on Latin American inequality in the long run. Buenos Aires.

Arroyo, L., \& Lindert, P. (2014). Fiscal redistribution in Latin America since the nineteenth century. In Conference on Latin American inequality in the long run. Buenos Aires.

Astorga, P. (2014). Functional inequality in Latin America: 1900-2011. In Conference on Latin American Inequality in the Long Run. Buenos Aires.

Atkinson, A. B. (1997). Bringing income distribution in from the cold'. The Economic Journal, 107(441), 297-321.

Atkinson, A. B., \& Piketty, T. (2010). Top incomes over the twentieth century: A global perspective. Oxford: Oxford University Press. 
Bárcena, A., \& Kacef, O. (Eds.). (2011). La política fiscal para el afianzamiento de las democracias en América Latina. Reflexiones a partir de una serie de estudios de caso. Santiago de Chile: ECLAC.

Barro, R. (2000). Inequality and growth in a panel of countries. Journal of Economic Growth, 5(1), 5-32.

Bastagli, F., Coady, D., \& Gupta, S. (2012). Income inequality and fiscal policy. IMF Staff Discussion Note SDN/12/08.

Berg, A. G., \& Ostry, J. D. (2011). Equality and efficiency. Finance and Development, 48(3), $12-15$.

Bértola, L. (2005). A 50 años de la curva de Kuznets: crecimiento económico y distribución del ingreso en Uruguay y otras economías de nuevo asentamiento desde 1870. Investigaciones de Historia Económica, 3, 135-176.

Bértola, L., \& Ocampo, J. A. (2012). The economic development of Latin America since independence. Oxford: Oxford University Press.

Chin, G., \& Culotta, E. (2014). The science of inequaltiy. What the numbers tell us. Science, 344(6186), 819-821.

Clifton, J., \& Díaz-Fuentes, D. (2014). The OECD and the rest: Analyzing the limits of policy transfer. Journal of Comparative Policy Analysis, 16(3), 249-265.

Comín, F., \& Díaz-Fuentes, D. (2005). Sector público administrativo y Estado del Bienestar. In Estadísticas históricas de España: siglos XIX-XX. Bilbao: Fundación BBVA.

Cornia, G. A. (2012). Inequality trends and their determinants: Latin America over 1990-2010. UNU-WIDER Working Paper 2012/09.

Cornia, G. A. (Ed.). (2014a). Falling inequality in Latin America: Policy changes and lessons. Oxford: WIDER Studies in Development Economics, Oxford University Press.

Cornia, G. A. (2014b). Income inequality in Latin America: Recent decline an prospects for its further reduction. DISEI-Università degli Studi di Firenze Working Papers-Economics $14 / 2014$.

Cornia, G. A., Gómez-Sabaini, J. C., \& Martorano, B. (2014). Tax policy and income distribution during the last decade. In G. A. Cornia (Ed.), Falling inequality in Latin America: Policy changes and lessons. Oxford University Press.

De la Torre, A. (2014). The inequality story in LAC: Searching for an explanation. In Conference on Latin American inequality in the long run. Buenos Aires.

Deininger, K., \& Squire, L. (1996). A new data set measuring income inequality. World Bank Economic Review, 10, 565-591.

Deininger, K., \& Squire, L. (1998). New ways of looking at old issues: Inequality and growth. Journal of Development Economics, 57, 249-287.

Díaz Fuentes, D. (1994). Fraude y Amnistías Fiscales en la España contemporánea 1940-1990. Hacienda Pública, 1(94), 389-402.

Díaz-Fuentes, D., \& Revuelta, J. (2011). Gasto público y crecimiento económico en América Latina y España entre 1960 y 2000. Revista Uruguaya de Historia Económica, 1, 12-33.

Díaz-Fuentes, D., \& Revuelta, J. (2013). La relación a largo plazo entre crecimiento económico y gasto público en España (1850-2000). Investigaciones de Historia Económica, 9(1), 32-42.

ECLAC. (2010). Time for equality: Closing gaps, opening trails. Santiago de Chile: UN-ECLAC.

ECLAC. (2014). CEPALSTAT. Santiago de Chile: Economic Commission for Latin America and the Caribbean.

FitzGerald, V., Heyer, J., \& Thorp, R. (Eds.). (2011). Overcoming the persistence of inequality and poverty. UK: Palgrave-Macmillan.

Gómez Sabaini, J. C., \& Martner, R. (2008). América Latina: Panorama global de su sistema tributario y principales temas de política. Santiago de Chile: Latin American and Caribbean Institute for Economic and Social Planning (ILPES)-ECLAC.

Goñi, E., López, J. H., \& Servén, L. (2011). Fiscal redistribution and income inequality in Latin America. World Development, 39(9), 1558-1569. 
González, I., \& Martner, R. (2012). Overcoming the "empty box syndrome”. Determinants of income distribution in Latin America. Cepal Review, 108, 7-25.

Hausmann, R. (1997). Foreward. In Latin America after a decade of reforms. Washington, DC: Inter-American Development Bank.

Higgins, M., \& Williamson, J. G. (1999). Explaining inequality the world round: Cohort size, Kuznets curves, and openness. NBER Working Paper no. 7224.

Huber, E., Nielsen, F., Pribble, J., \& Stephens, J. D. (2006). Politics and inequality in Latin America and the Caribbean. American Sociological Review, 71, 943-963.

Hvistendahl, M. (2014). While emerging economies boom, equality goes bust. Science, 344, $832-835$.

Irigoin, A., \& Giardili, S. (2014). The short-run effect of afirmative action on human capital accumulation incentives. In Conference on Latin American inequality in the long run. Buenos Aires.

Kuznets, S. (1953). Shares of upper income groups in income and savings. New York: National Bureau of Economic Research.

Kuznets, S. (1955). Economic growth and income inequality. American Economic Review, 45, $1-28$.

Lee, H. Y., Kim, J., \& Cin, B. C. (2013). Empirical analysis on the determinants of income inequality in Korea. International Journal of Advanced Science and Technology, 53, 95-109.

Lindert, P. H. (2004). Growing public. Social spending and economic growth since the eighteen century. Cambridge: Cambridge University Press.

Loayza, N., Mier y Terán, A., \& Rigolini, J. (2013). Poverty, inequality and the local natural resource curse. IZA Discussion Papers 7226.

Lustig, N., \& Lopez-Calva, L. F., \& Ortiz-Juarez, E. (2013). Deconstructing the decline in inequality in Latin America. World Bank Policy Research Working Paper 6552. doi: 10.1596/1813-9450-6552.

Marshall, M. G., Gurr, T. R., \& Jaggers, K. (2014). Polity IV project: Political regime characteristics and transitions, 1800-2013. Center for Systemic Peace.

McLeod, D., \& Lustig, N. (2011). Inequality and poverty under Latin America's new left regimes. Tulane Economics Working Paper Series 1117.

Milanovic, B. (1994). Determinants of cross-country income inequality: An "Augmented” Kuznets hypothesis. World Bank Policy Research Working Paper 1246.

Milanovic, B. (2013). The inequality possibility frontier: Extensions and new applications. World Bank Policy Research Working Paper 6449.

Milanovic (2014). All the ginis dataset. World Bank. http://go.worldbank.org/9VCQW66LA0

Milanovic, B., \& Muñoz de Bustillo, R. (2008). La desigualdad de la distribución de la renta en América Latina: situación, evolución y factores explicativos. América Latina Hoy, 48, $15-42$.

Montecino, J. A. (2011). Decreasing inequality under Latin America's "Social Democratic" and "Populist" governments: Is the difference real? Center for Economic Policy Research.

MOxLAD (2014). Montevideo Oxford Latin American economic history database. Universidad de la República, Montevideo. http://moxlad.fcs.edu.uy/en.html.

OECD. (2008). Growing unequal? Income distribution and poverty in OECD countries. Paris: OECD Publishing.

OECD (2015). OECD.StatExtracts. http://stats.oecd.org/

Okun, A. M. (1975). Equality and efficiency: The big trade-off. Washington: Brookings Institution Press.

Ostry, J. D., Berg, A., \& Tsangarides, C. G. (2014). Redistribution, inequality, and growth. Staff Discussion Note 14/2. Washington: International Monetary Fund.

Piketty, T. (2014). Capital in the twenty-first century. Cambridge, MA: Belknap.

Piketty, T., \& Saez, E. (2014). Inequality in the long run. Science, 344, 838-842.

Ravallion, M. (2014). Income inequality in the developing world. Science, 344, 851-855.

Roine, J., Vlachos, J., \& Waldenström, D. (2009). The long-run determinants of inequality: What can we learn from top income data? Journal of Public Economics, 93, 974-988. 
Salazar, H. (2014). Desigualdad en la última década. In Conference on Latin American inequality in the long run. Buenos Aires.

Sánchez-Ancochea, D. (2014). Inequality and the elite: Chile in historical perspective. In Conference on Latin American inequality in the long run. Buenos Aires.

SEDLAC (2014). Socio-economic database for Latin America and the Caribbean. CEDLASWorld Bank.

Székely, M. (2014). Declining inequality in LAC during the 21st Century: ¿structural shift, or temporary improvement? In Conference on Latin American inequality in the long run. Buenos Aires.

Székely, M., \& Sámano-Robles, C. (2014). Trade and income distribution in Latin America: Is there anything new to say? In G. A. Cornia (Ed.), Falling inequality in Latin America. Oxford University Press.

Tsounta, E., \& Osueke, A. I. (2014). What is behind Latin America's declining income inequality? IMF Working Paper 14/124.

Williamson, J. G. (2010). Five centuries of Latin American income inequality. Revista de Historia Económica/Journal of Iberian and Latin American Economic History, 28(2), 227-252.

World Bank (2014). World development indicators. Washington: World Bank. http://data.worldbank.org/data-catalog/world-development-indicators.

World Bank. (2006). World development report 2006: Equity and development. Washington: World Bank.

Judith Clifton is Professor at the Faculty of Business and Economic Sciences and Editorin-Chief of Journal of Economic Policy Reform. She serves on the editorial board of Utilities Policy and Annals of Public and Cooperative Economics and has guest edited in journals such as Cambridge Journal of Regions, Economy and Society, Business History, Review of International Political Economy, and Global Policy. She has published in leading international journals including Journal of European Public Policy, Journal of Regulatory Economics, Regional Studies, Health Policy, Cambridge Journal of Regions, Economy and Society, Review of International Political Economy, Public Administration, Journal of Comparative Policy Analysis, International Review of Applied Economics, Revista de Economía Mundial, and Global Policy.

Daniel Díaz-Fuentes is Full Professor of Economics at the University of Cantabria, Santander. He received his Ph.D. from the University of Alcalá (Madrid) and has since been Visiting Research Fellow at universities including Michigan, Oxford, London School of Economics, Manchester, European University Institute, and Cornell. He has worked as a consultant for the United Nations and European Commission. He has published on topics including the Public Service Reforms, International Financial Institutions, and Economic Development in prestigious international reviews. His main areas of research interest include Fiscal and Taxation Policies, Privatization, Regulation, New Public Management, and Foreign Direct Investment policies, with particular expertise on Europe and Latin America.

Julio Revuelta holds a Ph.D. in Economics from the University of Cantabria. He is Lecturer in the Department of Economics at the University of Cantabria. He has been visiting researcher at Trinity College Dublin and Politecnico di Milano. He has published his research work in prestigious international journals such as Journal of European Public Policy, Utilities Policy, Economics of Governance, International Review of Applied Economics, and Revista de Economía Mundial. 